\title{
Russian University Oriental Studies and Sinology in Kazan and Teaching Chinese in the First Kazan Gymnasium (The First Half of the XIX Century)
}

\author{
Ramil M. Valeev ${ }^{1}$, Roza Z. Valeeva ${ }^{1}$, Ruslan G. Fedorchenko ${ }^{1} \&$ Rimma R. Sagitova ${ }^{1}$ \\ ${ }^{1}$ Kazan (Volga Region) Federal University, Kazan, Russia \\ Correspondence: Ramil M. Valeev, Kazan (Volga Region) Federal University, Kremlyovskaya street, 18, Kazan \\ 420008, Russia. E-mail: valeev200655@mail.ru; ram.valeev2016@yandex.ru
}

Received: April 14, 2015 Accepted: April 20, 2015 Online Published: April 27, 2015

doi:10.5539/jsd.v8n4p38 URL: http://dx.doi.org/10.5539/jsd.v8n4p38

\begin{abstract}
Formation of the Russian academic and university sinology, institutional stages, tendencies and features of development of oriental studies as educational and scientific discipline - one of the most important theoretical and applied problems. The XIX century demonstrated the main educational, scientific and organizational and research stages of formation and development of university oriental studies and sinology in Russia and Europe. Especially Kazan and St. Petersburg universities were the largest centers of Russian and European orientalism, including sinology of the XIX - the beginning of the XX centuries. In the basis of the Russian oriental studies, including sinology were external and internal political, trade and economic, scientific and cultural relations with countries of the East, major problems of socio-cultural development of the East of Russia and foreign Asia, the European oriental science and education and, in particular, original national research schools and cultures of the Eastern peoples of Russia. Kazan and the Kazan University have played a crucial role in formation and development of education and science about the East. The main aim of this article is to submit the review of development of the Kazan center of Russian university oriental studies, in particular sinology in the first half of the XIX century, the main activities and a contribution of professors and teachers to studying of history and culture of China at imperial Kazan university and teaching Chinese in the First Kazan gymnasium.
\end{abstract}

Keywords: oriental studies, Sinology, Russian sinologists, teaching Chinese, Kazan University, first Kazan gymnasium

\section{Introduction}

Interstate and socio-cultural interaction of Russia - China - the West and especially practical, academic and university study of language, literature, history and culture of Chinese's peoples has become an important factor of origin and development of sinology in Russia and Europe in the XVIII - beginning of the XX centuries (Skachkov, 1977; Istoriya otechestvennogo vostokovedeniya do seredinyi XXI veka,1990; Istoriya otechestvennogo vostokovedeniya s seredinyi XIX veka do 1917 g., 1997; Kulikova, 1993; Pan \& Shatalov, 2004; Datsyishen, 2006; Zurndorfer, 1995; Kampen, 2000; Ming, 2005).

Formation of the Kazan university sinology, Mongolian studies, Buddhist studies and Manchu studies in the first half of the XIX century which are based on studying of languages and monuments of spiritual culture of peoples of Central and East Asia, particularly China, is connected with activity of famous scientists and participants of the Beijing spiritual mission - the archimandrite Daniil (1798-1871, Beijing, 1821-1830), I.P. Voytsekhovsky (1793-1850, Beijing, 1819-1831) and V.P. Vasilyev (1818-1900) - the pupil of the eastern division, also the member of mission in 1840-1850. The university Department of Chinese language and Literature (1837) transformed in 1844 to the Department of Sino-Manchu literature, and researches of the Kazan orientalists represented the origin and development of university tradition of studying Far East civilizations and states in Russia and Europe.

\section{Methodological Framework}

Methods of this research are based on use of the various modern principles and ideas - the world outlook, epistemological and logical, which play an important role in studying events, stages and the directions of formation of the Russian sinology, including the Kazan university center of Sinology. 
The comparative-historical principle is the fundamental method of this research. It allows highlighting the formation and development of a university sinology in Russia and Europe in close connection with historical factors, as well as a social and political situation in Russia in the XIX - the beginning of the XX centuries.

The next method of research is a periodization of history of the Russian oriental studies, including the history of the Kazan center of sinology. At the core of the periodization of history of the Kazan university sinology of the XIX - the beginning of the XX centuries - the objective and subjective criteria allowing to light institutional forms of oriental studies, including sinology in Russia and Europe, research methods and nature of teaching and scientific activity of the Russian orientalists and sinologists, etc. Application of this method in the article is connected with fixation of a chronological framework of process of formation and development of sinology in Kazan and in general in Russia and

Europe.

The method of system approach in studying of a subject allows considering its main components and their interaction - sinology at the university, biography and heritage of professors and teachers, historical and scientific events devoted to studying of history and culture of China, etc.

Chronological and problem-chronological methods of research and presentations in sequence and coherence promote publicizing of formation of sinological education and university discipline in Kazan. This method of studying history of formation of sinology at the university, preparation and publication of sources, textbooks and programs, teaching Chinese in the First Kazan gymnasium and university is important not only for the history of the Kazan oriental studies, but also for an assessment of the Russian and world oriental studies and sinology of the $\mathrm{XIX}$ - the beginning of the XX centuries.

In general various methods of this research allow covering general, special and single phenomena and facts in the development of the university sinology in Kazan. In the history of the Kazan university oriental studies and sinology of the XIX - the beginning of the XX centuries along with the general tendencies, typical for the main centers of orientalism in Russia and Europe, single and unique ones are identified.

\section{Results}

At the end of the XVIII - the first half of the XIX century the scientific direction and discipline "East literature and antiquity" represented the nature of the academic and university oriental studies in Russia. In the last quarter of the XIX century the leading scientists-orientalists formulated wider socio-cultural problem of domestic oriental studies - to transfer to students and to generalize "all knowledge concerning the East gained by science, but not only its languages" (Bartold, 1977). At the beginning of the XX century the oriental studies in Russia and Europe represented a complex system of knowledge of history and culture of the peoples of the East. East linguistics and researches of traditional oriental script and material culture became a foundation of created classical oriental studies in Russia at the beginning of the XX century. In the XIX - the beginning of the XX centuries the academic and university directions of the Russian oriental studies are characterized by interaction with the state and society, subject updating and change of a role of regional scientific disciplines (Arabic studies, Turkology, Sinology, Mongolology, etc.), the appearance of new forms of the organization of researches and institutional association of scientists-orientalists, the international scientific and cultural contacts with Asia and Europe.

At the turn of the XVIII - the beginning of the XIX centuries Kazan was the large socio-political, trade and economic and cultural center of the east of the Russian Empire. Occupying an important strategic boundary between West-Russia-East, the main conditions for development of oriental studies were created in Kazan. In the first half of the XIX century the Kazan University became the key center of the Russian and world university oriental studies, including sinology.

Especially in the XIX - the beginning of the XX centuries Kazan as the meeting point of two worlds - western and easten (A. Herzen) became the center of the Russian and world oriental studies. The trustee of the Kazan educational district M.N. Musin-Pushkin (1795 - 1862) wrote: "Kazan, connecting the European Russia with Asian, serving as a stowage for east goods, attracting Asiatic with extensive trade, including many Tatars quite educated and trained in Bukhariya, - is... that place where without big expenses theoretical and practical studying of oriental languages can easily be connected" (Rossiyskiy gosudarstvennyiy istoricheskiy arhiv. Fond.733. Opis.41. Delo. 86. List.2).

The university oriental studies in Kazan takes an important place in the history of domestic and world orientalism of the XIX-XX centuries. Teaching a variety of oriental languages and conducting oriental scientific researchers at the university and in other educational and scientific centers are represented by the phenomenon of 
Russian and European policy, culture and science. Scientific and pedagogical activity of orientalists considerably promoted further formation and development of oriental studies as a classical humanitarian education and science. Their works still represent the most valuable sources of scientific researches and history of the Russian and world oriental studies. The category of oriental literature and especially Oriental Departments (Turko-Tatar literature, Arab-Persian literature, Mongolian literature, Chinese-Manchu literature, Sanskrit literature, etc.) of the University in Kazan laid the foundation to systematic and comprehensive oriental education in Russia and Europe.

During the XIX - the beginning of the XX centuries in Kazan university oriental studies, including sinology there had been organizational, research and socio-cultural changes. This period, despite the critical milestones in the history of oriental studies at Kazan University, is characterized by progressiveness and continuity of a development of education and science (Valeev, 1998; Schimmelpenninck van der Oye, 2010).

The university oriental studies in Kazan in the first half of the XIX century was formed and developed on the basis of the organization of scientific travel to the countries of the Muslim East, Central and East Asia. Along with the practical training of pupils with native speakers of Asian languages direct acquaintance with the history, languages, culture, everyday life and customs during research trips and travels were prominent factors of the development of the Kazan school of orientalists of the XIX - beginning of the XIX centuries.

In the Russian imperial oriental studies of the XVIII - the beginning of the XX centuries China caused huge interest and the Beijing spiritual mission, where the representatives of the university centers were also sent, played a special role in the development of Russian-Chinese relations and formation of the Russian sinology

(Skachkov,1977; Istoriya otechestvennogo vostokovedeniya do seredinyi XIX veka, 1990; Istoriya otechestvennogo vostokovedeniya s seredinyi XIX veka do 1917 goda, 1997; Datsyishen, 2010). Research trips to China and participation in the Beijing spiritual mission of a mongolist O.M. Kovalevskiy (1800-1878) and famous orientalist-sinologist V.P. Vasilyev (1818-1900) take an important place in the history of the Kazan university oriental studies and sinology of the first half of the XIX century (Rossiyskiy gosudarstvennyiy istoricheskiy arhiv. Fond.733. Opis.40. Delo.318; Natsionalnyiy arhiv Respubliki Tatarstan. Fond.92. Opis.1. Delo. 3829; Valeev, Ermakova, Kulganek, 2014; Rossiya-Mongoliya-Kitay: Dnevniki mongoloveda O.M.Kovalevskogo 1830-1831 gg., 2005).

History of academic and university domestic sinology of the XIX century is presented by bright and outstanding names of scientists-sinologists and their priceless heritage devoted to history and culture of the great neighbor of Russia - China. The following names should be especially distinguished - N.Ya. Bichurin (1777-1853), P.I. Kamensky (1765-1845), S.V. Lipovtsov (1770-1841), P.I. Kafarov (1817-1878) and V.P. Vasilyev (1818-1900). They are all in different years lived and studied in Kazan, and the thorny path to a science of China was connected to the Russian spiritual mission in Beijing. Especially Bichurin, Kafarov and Vasilyev's heritage made an era in the Russian sinology of the XIX century - science about the East that study China, its people, language, history and culture. Their biography and destiny are closely woven and generally reveal the greatness and tragedy of scientific creativity and the search of the first Russian scientists-sinologists, who laid the foundation of classical sinology in Russia.

Formation of the Russian university sinology in Kazan is connected with the following events and names. On May 11, 1837 the Department of Chinese language and literature was opened for the first time in Russia, in 1844 it was transformed to Chinese-Manchurian Department (Natsionalnyiy arhiv Respubliki Tatarstan. Fond.92. Opis.1. Delo. 4599; Rossiyskiy gosudarstvennyiy istoricheskiy arhiv Fond.733. Opis.42. Delo.5).

For example, original pages of formation of the Kazan university sinology and preparation for sending to the Beijing spiritual mission are connected with the following historical and scientific facts and events. On March 14, 1838 a professor of Chinese archimandrite Daniil received the letter from the trustee of the Kazan educational district in which he was asked to evaluate the student Rushko's knowledge. A similar letter concerning the candidate Vasilyev and the student Navrotsky was received by the professor of the Mongolian language Osip Kovalevskiy. The trustee asked to estimate students' knowledge, intending afterwards "to send Rushko to Beijing to improve Chinese ", Vasilyev "to improve Tibetan", and the student Navrotsky "to improve Mongolian and study Manchu". (Natsionalnyiy arhiv Respubliki Tatarstan. Fond. 92 . Opis.1. Delo. 4814. Listy. 1-3 ob.).

In response letters teachers of the Chinese and Mongolian languages in March, 1838, the archimandrite Daniil and Osip Kovalevskiy positively praised the success of above-mentioned students and agreed that sending them on training abroad "will serve as the only means to deliver them all the possible ways to acquire deep knowledge in oriental languages" (Natsionalnyiy arhiv Respubliki Tatarstan. Fond. 92 . Opis.1. Delo. 4814. Listy. 1-3 ob.). Concerning studying of the Tibetan language, the ordinary professor Osip Kovalevskiy visiting in 1831 Beijing 
within the XI Beijing spiritual mission noted that "in the Chinese capital, as far as I know there are thousands of lamas from natural Tibetans, including those that know the Sanskrit language and various Indian dialects ".

Due to the alleged opening of the Department of the Tibetan language at the Kazan University it was decided to send V. Vasilyev to Beijing within the Spiritual mission who passed tests for the master's degree (Natsionalnyiy arhiv Respubliki Tatarstan. Fond. 92 . Opis.1. Delo. 4814. List. 14.). With V. Vasilyev's departure from Kazan on January 20, 1840 within the XII spiritual mission on a long trip to China a new page in the life of a young scientist was opened, where, according to him, "many of his thoughts and views" were born. A unique educational and scientific trip of V.P. Vasilyev to Beijing (from January, 1840 to September, 1850) who continued the tradition of scientific journeys in the history of the Russian oriental studies of the XIX century played a crucial role in his scientific destiny. This scientific trip was a turning point in the history of the Russian university sinology of the XIX century. In the history of the Russian spiritual mission in Beijing (1715-1864) the graduate of the Russian university and the master of east literature was attached. In Beijing he developed observation, memory and amazing ability of scientific work on original Chinese texts. A profound scientific base of versatile knowledge of history and culture of the peoples of China was generally created.

In June, 1839 on the instructions of University Council professor O.M. Kovalevskiy (Natsionalnyiy arhiv Respubliki Tatarstan. Fond. 977. Opis. Soveta. Delo. 8453. Listy. 6-10) made a program for the student of the Kazan University sent to Beijing.

V.P. Vasilyev's program of practical classes ("Guided instruction") in Beijing became the original university educational and scientific program of complex training of the orientalist-sinologist, specialist of Tibetan, Buddhist and Munchu languages. In this program he fully carried out significant ideas and principles: "university education ..., not being limited to a single theory of languages, promotes pupils to their practical use of language, and explaining the history and literature of the major Asian people, opens a way for further development of the richest sources of oriental study, for the benefit and glory of our Fatherland" (Kovalevskiy, 1837).

In this program special attention was paid on studying of the Tibetan and Sanskrit languages, "Tibetan history, literature and antiquities", collecting data on China, India and Mongolia, acquisition of books and manuscripts, etc. Future ordinary academician V.P. Vasilyev was appointed the agent-correspondent of Academy of Sciences in order to acquire Tibetan and Mongolian books, and also for performance of other academic scientific instructions. In addition to the instruction of the university and Academy of Sciences (Natsionalnyiy arhiv Respubliki Tatarstan. Fond. 977. Opis. Soveta. Delo. 8453. Listy.11-12) the trustee ordered to give additional tasks on collecting of rare items for enrichment of zoological museum, herbarium, etc. for the Kazan University (Natsionalnyiy arhiv Respubliki Tatarstan. Fond. 977. Opis. Soveta. Delo. 8453. List.5). In the instruction to the traveler made by O. Kovalevskiy it is noted that the Kazan university, sending V. Vasilyev to Beijing within the Russian spiritual mission for a period of ten years, hopes over time to get in his face a great teacher of the Tibetan language and deep researcher of geography, history, religion and antiquities of the people inhabiting "east strip of Asia" (Natsionalnyiy arhiv Respubliki Tatarstan. Fond. 977. Opis. Soveta. Delo. 8453. List.5). Deep study of the Tibetan language, and also its dialects, as emphasized, was the first and most important task and a main purpose of the future scientist (Natsionalnyiy arhiv Respubliki Tatarstan. Fond. 977. Opis. Soveta. Delo. 8453. List.5). For these purposes V. Vasilyev was asked to pay attention to the compilation of "lexicon" on the basis of the Tibetan works of different periods, etc.

The organization and teaching of oriental languages in secondary schools had huge political and socio-cultural value in the history and culture of the peoples of the Russian Empire. The origins of the Russian oriental studies, in particular the Kazan orientalism and sinology of the XIX century are originally connected with teaching and studying of oriental languages in secondary schools of Russia. The important role was played by the Kazan First men's gymnasium (1758-1918, till 1788 Kazan gymnasium, till 1835 Imperial Kazan gymnasium).

Teachers of oriental languages for secondary schools and interpreters for the departments of management of Eastern areas of the Russian Empire were trained at the first Kazan gymnasium and the division of the eastern literature of the Kazan University before its closing in 1854/1855. In the first half of the XIX century in the gymnasium the following oriental languages were taught - the Arab, Persian, Mongolian, Manchu and Chinese. It is known that among graduates of the gymnasium there are outstanding Russian scientists and cultural figures: G.R. Derzhavin, S.T. Aksakov, N.I Lobachevsky, A.M Butlerov, A.E. Arbuzov, Dorzhi Banzarov, A.V. Popov, K. K. Foygt, G. A. Vagapov, S. Sh. Alkyne, etc.

Teaching Chinese in the gymnasium had huge value in the development of university sinology in Kazan and in Russia in general.

The first professor of Chinese at the Kazan University was archimandrite Daniil (D.P. Sivillov (1798-1871), who 
taught in 1837-1844. I.P. Voytsekhovsky (1793-1850) who laid the foundation of a scientific Munchu study in Kazan in 1844-1850 became the successor of the archimandrite Daniil at the Kazan University. In 1851-1855 the Department was headed by V.P. Vasiliev (1818 - 1900). They played a crucial role in the formation of a tradition of teaching Chinese at the university and the First Kazan gymnasium.

At the beginning of 1837 to the position of ordinary professor of Chinese, established by the Department of Eastern literature, the archimandrite of the Moscow Zlatoust monastery Daniil was invited and he served at the university until 1844. On May 11, 1837 at the Kazan imperial university the Russia's first Department of Chinese language was opened (Natsionalnyiy arhiv Respubliki Tatarstan. Fond.92. Opis.1. Delo. 4599; Rossiyskiy gosudarstvennyiy istoricheskiy arhiv. Fond.733. Opis.40. Delo.318; Rossiyskiy gosudarstvennyiy istoricheskiy arhiv Fond.733. Opis.42. Delo.5; Natsionalnyiy arhiv Respubliki Tatarstan. Fond.92. Opis.1. Delo. 5451).

After the beginning of teaching Chinese at the university there was a question of the organization of its study in the First Kazan gymnasium. On November 3, 1838 by the special order of the trustee of the educational district teaching Chinese was introduced in the gymnasium. Duties of the lecturer were assigned to the university professor archimandrite Daniil. In 1838 the Kazan educational district trustee approved the provincial secretary of Alexey Sosnitsky (1792 - 1843) as the supervisor for practical classes for grammar-school boys. He is known as a junior deacon of the Russian spiritual mission in Beijing (1821 - 1830), interpreter and teacher of Chinese in gymnasium and the Kazan University in 1838 - 1843. Since 1839, in addition to the Chinese language, students had to study Mongolian language. Thus, close connection of sinology and Mongolian studies in educational and scientific programs of the university and gymnasium is noticeable.

In 1841 professor D. Sivillov made the first program of teaching Chinese in the Kazan gymnasium. In 1841 at the Kazan University there was the first graduation of students who completed the course of the Chinese Literature. Sergey Rushko (1819 - 1845) was one of the best graduates. Since September 23, 1841 Sergey Rushko started to teach Chinese and taught languages in the gymnasium and university until his death in 1845 .

In February, 1844 due to the archimandrite Daniil's petition for his dismissal to a position of professor of the Chinese and Manchu languages I.P. Voytsekhovsky, the doctor of spiritual mission in Beijing (1819 - 1831) was invited and also the staff of the Ministry of Foreign Affairs of the Russian (1832 - 1844). In April, 1844 I.P. Voytsekhovsky was approved as a professor of Chinese with an assignment of teaching Manchu. In August, 1844 he arrived to the Kazan university where taught until his death in 1850. For this period he managed to write only several teaching programs and textbooks which were used in teaching of Chinese and Manchu in the gymnasium and university. In Kazan I.P. Voytsekhovsky finished compiling "The Chinese-Manchu-Russian dictionary". (Istoriya otechestvennogo vostokovedeniya do seredinyi XIX veka, 1990). He was the first who laid the foundation to university school of Manchurian philology and linguistics in Russia.

In the 40th - the first half of the 50th of the XIX century there were essential changes in the organization and a technique of studying of Asian languages, including the Chinese and Manchu languages in the First Kazan gymnasium. According to the project of 1845 "Regulations on Asian Languages teaching in the First Kazan Gymnasium" teaching languages of the Qing Empire was planned on two categories: Chinese-Manchu and Mongolian-Manchu. From 80 grammar-school boys of the educational institution 15 pupils had to study oriental languages, including 2 grammar-school boys - Chinese and Manchu and 2 grammar-school boys - Manchu and Mongolian (Natsionalnyiy arhiv Respubliki Tatarstan. Fond.92. Opis.1. Delo. 3833. Listy.4-6 ob.).

A new program of teaching Chinese in the First Kazan gymnasium was made by Professor I.P. Voytsekhovsky in 1845. According to the program the general course of studying Chinese had to be five years (Natsionalnyiy arhiv Respubliki Tatarstan. Fond.92. Opis.1. Delo. 3833. Listy. 26-21). The main purpose of the first year training was acquisition of basic concepts of the Chinese language, and also the main keys that make up all the words. The second course began with grammar studying, small translations from Chinese into Russian and vice versa. Etymology and syntax of Chinese were studied on the third course. On the fourth the special attention was paid to the differences between bookish and colloquial Chinese. The fifth-year students had to translate classical books independently. As a preparation for the civil service the translations of official papers, letters and historical stories were introduced.

Owing to A. Sosnitsky's death in 1843 and S. Rushko's resignation for health reasons in May, 1845 the position of the teacher of Chinese in the gymnasium remained vacant. In December, 1845 Ivan Ladukhin (? - 1857) successfully defended thesis and got the degree of doctor of Chinese literature. On January 12, 1846 he was recommended to the position of a senior teacher in the Kazan gymnasium. He played an important role in further development of teaching Chinese in gymnasium. In the late forties of the XIX century on the initiative of the professor I. P. Voytsekhovsky and the teacher I. Ladukhin the discussion on introduction of the Manchu language 
teaching in the First Kazan gymnasium started.

The program of Manchu teaching in the gymnasium made by I. Ladukhin was presented to V.P. Vasilyev. He considered that "the introduction of the Manchu language teaching in the First Kazan gymnasium was... not only useful, but also necessary". This program was approved by the professor V.P. Vasilyev (Natsionalnyiy arhiv Respubliki Tatarstan. Fond. 92. Opis. 1. Delo. 6504. List.6). In 1851 the trustee of the Kazan educational district V.P. Molostvov (1847 - 1857) allowed to introduce classes in the Manchu language in the First Kazan gymnasium according to the program made by I.A. Ladukhin (Natsionalnyiy arhiv Respubliki Tatarstan. Fond. 92. Opis. 1. Delo. 6504. List. 7).

In 1851-1854 Chinese was taught by Abdekarimov Ismail (1800-1865) in the gymnasium. In $1853-1854$ he also conducted practical classes in Chinese on the eastern division of university. In 1854 professor V.P. Vasilyev, estimating his activity on this position wrote: "Practical Chinese language teaching gratuitously undertaken at the University by the supervisor of the First Kazan Gymnasium Abdulkerimov last year undoubtedly is very useful; in general, the opportunity to gain practical knowledge of Chinese from the native Chinese is perhaps the only one in Europe" (Natsionalnyiy arhiv Respubliki Tatarstan. Fond.977. Opis. Istoriko-filologicheskiy fakultet. Delo.726. List.84). In general in the first half of the XIX century sinology is registered as educational and scientific discipline at the Kazan university. This was the beginning of university complex studying of languages, geography, history and cultural heritage of the Chinese civilization.

\section{Discussions}

Today the scientific projects are carried out by the scientists of oriental centers in Kazan, Moscow, St. Petersburg, Krasnoyarsk, Ulan-Ude, Kiev, Baku, Warsaw and Berlin. That make possible to systematize and evaluate more deeply the facts and events of origin and development of university oriental studies and sinology in Kazan and in other centers of Russia in the XIX - the first quarter of the XX centuries and its organic relations with the domestic and European centers of oriental studies. Further historical and scientific research of history of the Kazan oriental studies of the XIX-XX centuries as an integral part of the Russian and European orientalism is an urgent need of modern Russian and foreign historiography, source studies, cultural studies and science studies.

\section{Conclusion}

Educational, scientific and educational activities of the Kazan sinologists and subsequently their students have identified the main ways of development of Russian sinology, Mongolian studies, Buddhist studies and Manchu studies in the XIX century. Their researches have become an important part of the history of Russian and world oriental studies and sinology. The scientific fate of the Kazan orientalists reflected the general and special in the development of classical sinology in Russian cultural and historical sphere. They carried on the best pedagogical and scientific traditions of Russian orientalists-sinologists of the XVIII century. Unfortunately, the centralization of oriental education and science at the faculty of Oriental languages of the St. Petersburg University in 1854/1855 reflected in teaching of Asian languages in gymnasiums, colleges and universities in Russia in the second half of the XIX century. Teaching languages, history and literature of China at the Kazan University and the First Kazan gymnasium stopped with closing of the eastern division of the Kazan University.

\section{Recommendations}

Materials and conclusions of the article extend the study of the theoretical and conceptual, historical, scientific, historiographic and source studies problems of history of the Russian oriental studies and sinology of the XIX the first quarter of the XX centuries. Facts, events and new archival materials presented in the paper can be used for further development of the concept of history of the Russian and European oriental studies of the XIX-XX centuries, its methodology as well as for the preparation of new monographs and generalizing works on the history of oriental studies in Russia and Europe. It can also be used in lecture courses on the history of the East, Russian and foreign historiography and source studies.

\section{Acknowledgments}

The work is performed according to the Russian Government Program of Competitive Growth of Kazan Federal University.

\section{References}

Bartold, V. V. (1977). Obzor deyatelnosti fakulteta vostochnyh yazykov. Sochineniya. T.1X. Raboty po istorii vostokovedeniya. Moskva, 176.

Datsyishen, V. G. (2006). Istoriya izucheniya kitayskogo yazyika v Rossiyskoy imperii: izd. 2-e, ispr. i dop. Blagoveschensk. 
Datsyishen, V. G. (2010). Istoriya Rossiyskoy duhovnoy missii v Kitae. - Gonkong - Bratstvo Svyatyih Pervoverhovnyih Apostolov Petra i Pavla.

David Schimmelpenninck van der Oye. Russian Orientalism. (2010). Asia in the Russian Mind from Peter the Great to the Emigration. Yale University Press.

Istoriya otechestvennogo vostokovedeniya do seredinyi XXI veka. (1990). Moskva.

Istoriya otechestvennogo vostokovedeniya s seredinyi XIX veka do 1917 g. (1997). Moskva.

Kampen, T. (2000). China in Europe: A Brief Survey of European China Studies at the Beginning of the Twenty-first Century. China Review International, 7(2), 291-295. http://dx.doi.org/10.1353/cri.2000.0083

Kovalevskiy, O. M. (1837). O znakomstve evropeytsev s Aziey. Rech, proiznesennaya v torzhestvennom sobranii imperatorskogo Kazanskogo universiteta, 8-y den avgusta 1837 g. ordinarnyim professorom Osipom Kovalevskim. Kazan: 36.

Kulikova, A. M. (1993). Vostokovedenie v rossiyskih zakonodatelnyih aktah (konets XVII v. — 1917 g.). Sankt-Peterburg.

Ming, W. (2005). Europe Studies China: Papers from an International Conference on the History of European Sinology. London, 111-136.

Natsionalnyiy arhiv Respubliki Tatarstan. Fond. 92 . Opis.1. Delo, 4814.

Natsionalnyiy arhiv Respubliki Tatarstan. Fond. 92. Opis. 1. Delo, 6504.

Natsionalnyiy arhiv Respubliki Tatarstan. Fond. 977. Opis. Soveta. Delo, 8453.

Natsionalnyiy arhiv Respubliki Tatarstan. Fond.92. Opis.1. Delo, 3829.

Natsionalnyiy arhiv Respubliki Tatarstan. Fond.92. Opis.1. Delo, 3833.

Natsionalnyiy arhiv Respubliki Tatarstan. Fond.92. Opis.1. Delo, 4599.

Natsionalnyiy arhiv Respubliki Tatarstan. Fond.92. Opis.1. Delo, 5451.

Natsionalnyiy arhiv Respubliki Tatarstan. Fond.977. Opis. Istoriko-filologicheskiy fakultet. Delo, 726.

Pan, T. A., \& Shatalov O. V. (2004). Arhivnyie materialyi po istorii zapadnoevropeyskogo i rossiyskogo kitaevedeniya. Voronezh.

Rossiya-Mongoliya-Kitay: Dnevniki mongoloveda O.M.Kovalevskogo 1830-1831 gg. (2005). / Podgotovka k izdaniyu, predislovie, glossariy, kommentariy, ukazateli R.M.Valeev, I.V.Kulganek,. Kazan.

Rossiyskiy gosudarstvennyiy istoricheskiy arhiv Fond.733. Opis.42. Delo, 5.

Rossiyskiy gosudarstvennyiy istoricheskiy arhiv. Fond.733. Opis.40. Delo, 318.

Rossiyskiy gosudarstvennyiy istoricheskiy arhiv. Fond.733. Opis.41. Delo, 86.

Skachkov, P. E. (1977). Ocherki istorii russkogo kitaevedeniya. Moskva.

Valeev, R. M. (1998). Kazanskoe vostokovedenie: Istoki i razvitie (XIX v. - 20-e gg. XX v.). Kazan.

Valeev, R. M., Ermakova, T. V., \& Kul'ganek, I. V. (2004). Mongoloved O.M. Kovalevskij: biografiya i nasledie (1801-1878). Kazan.

Zurndorfer, T. H. (1995). China Bibliography A Research Guide to Reference Works about China Past and Present. Leiden, 4-45.

\section{Copyrights}

Copyright for this article is retained by the author(s), with first publication rights granted to the journal.

This is an open-access article distributed under the terms and conditions of the Creative Commons Attribution license (http://creativecommons.org/licenses/by/3.0/). 